\title{
PERLINDUNGAN HAK CIPTA PADA BUKU ELEKTRONIK (E-BOOK) DI INDONESIA
}

\author{
Ida Ayu Lidya Nareswari Manuaba, Fakultas Hukum Universitas Udayana, e- \\ mail: dayulidya@gmail.com \\ Ida Ayu Sukihana, Fakultas Hukum Universitas Udayana, e-mail: \\ ayu_sukihana@unud.ac.id
}

doi: https://doi.org/10.24843/KS.2020.v08.i10.p09

\begin{abstract}
ABSTRAK
Studi ini bertujuan untuk mengetahui pengaturan mengenai buku elektronik (e-book) menurut UndangUndang Hak Cipta Nomor 28 Tahun 2014 yang selanjutnya disebut dengan UUHC, dan mengetahui bentuk penyelesaian sengketa yang dapat ditempuh apabila terjadi pelanggaran hak cipta pada buku elektronik (E-book). Studi ini menggunakan metode penelitian hukum normatif dengan memusatkan objek kajian pada UUHC. Hasil studi menunjukkan bahwa penjelasan dari Pasal 40 Ayat (1) huruf n UUHC secara implisit mengakui bahwa buku elektronik (E-book) merupakan salah satu ciptaan adaptasi yang dilindungi. Maka dari itu buku elektronik (E-book) adalah bentuk adaptasi atau pengalihwujudan dari buku cetak sehingga buku elektronik (E-book) harus dilindungi. Bagi orang lain yang ingin mengkonversi buku cetak menjadi buku elektronik (E-book) harus mendapatkan izin dari penciptanya melalui perjanjian lisensi yang dibuat oleh para pihak dan harus memenuhi syarat sahnya perjanjian sebagaimana diatur dalam Pasal 1320 KUHPer. Apabila terdapat pelanggaran hak cipta dalam penggandaan buku elektronik tanpa seizin Pencipta maka berdasarkan Pasal 95 Ayat (1) UUHC perkara tersebut dapat diselesaikan melalui pengadilan dan tanpa melalui pengadilan. Penyelesaian sengketa tanpa melalui pengadilan dapat dilakukan dengan cara arbitrase, mediasi, negosiasi, dan konsiliasi. Khusus untuk jalur pengadilan, hanya Pengadilan Niaga yang berwenang untuk menyelesaikan perkara dalam bidang hak cipta.
\end{abstract}

\section{Kata kunci : Buku elektronik (E-book), Penyelesaian Sengketa, Hak Cipta}

\begin{abstract}
This study aims to find out the law of e-book or e-book copyright based on Copyright Law Number 28 Year 2014 which known as UUHC and the forms of how to settled any cases that is used if the e-book copyright occurs. This study use normative law methods and focusing to UUHC as the object of study. The study results show that the explanation from Article 40 Paragraph (1) letter $n$ of the UUHC implicity admit that e-book is one of protected adaptation creation. Therefore e-book can be interpreted as a form of aadaption or transformation of printed book so that e-book need to be protected. For those who want to convert a printed book into an e-book need the author permission through license agreement that made by each side and need to fulfill the legal terms of the agreement which regulated in Article $1320 \mathrm{BW}$. If there is a copyright infringement in duplicating books without the author permission, based on Article 95 Paragraph (1) UUHC this case can be settled by courts or without trial can be solved by arbitration, mediation, negotiation, and conciliation. Specifically for the case which can be settled by court, the court who own the authorization to settle the cases is Commercial Court.
\end{abstract}

Keyword: Electronic books (E-book), Dispute Resolution, Copyrights 


\section{Pendahuluan}

\subsection{Latar Belakang}

Hak Kekayaan Intelektual (KI) secara sederhana dipahami sebagai hak kebendaan yang tidak berwujud (intangible rights). Pengertian menurut salah satu pakar yang berkaitan dengan kekayaan intelektual, yaitu menurut David I Baindridge, Intellectual Property is the legal right which protect the product of the human intellect. Maknanya adalah bahwa melekatnya hak dalam kekayaan intelektual, yaitu hak atas kekayaan yang berasal dari karya intelektual manusia. ${ }^{1}$ KI menjadi faktor determinan dalam pencapaian tujuan pembangunan sosio-ekonomi, menyokong daya saing dalam dunia teknologi, serta menumbuhkembangkan inovasi dan kreativitas.

Salah satu bentuk KI yang diakui dan mendapatkan perlindungan adalah hak cipta. Perlindungan kekayaan intelektual khususnya di dalam bidang Hak Cipta sangat diperlukan karena melalui salah satu jenis KI ini dapat mempengaruhi hubungan ekonomi secara internasional, hal ini disebabkan oleh beberapa aspek yaitu pengaruh dari perkembangan dalam hal teknologi dan komunikasi sehingga muncul pasar global, dan adanya peningkatan keseriusan dan kualitas riset serta melakukan ekspansi pembaruan untuk menciptakan suatu produk yang baru, maka dari itu perlindungan dalam bidang hak cipta sangat dibutuhkan. ${ }^{2}$ Karena apabila perlindungan terhadap Hak Cipta itu tidak jelas atau belum dapat terealisasikan maka para investor asing pun akan enggan untuk berinvestasi dalam bidang KI ini dan akan menghilangkan peluang dalam mengembangkan hubungan ekonomi dalam ranah internasional, dan juga akan menghilangkan kesempatan untuk menjalin hubungan kerja sama dengan para investor maupun perusahaan asing.

Hak Cipta sebenarnya lebih mendasar pada Hak Eksklusif Penciptanya, hak eksklusif yang dimaksud yaitu pihak lain tidak diperkenankan untuk menggunakan hak tersebut untuk kepentingan apapun tanpa sepengetahuan atau izin dari pencipta atau dibenarkan berdasarkan undang-undang. Kendatipun demikian, keharusan untuk memperoleh izin dari pencipta seringkali diabaikan oleh plagiator dan pelanggar hak cipta. Hak eksklusif ini terdiri dari hak ekonomi dan hak moral, hak ekonomi yaitu hak dimana pencipta berhak memperoleh hasil atas ciptaannya, dan hak moral adalah hak yang melekat pada diri pencipta dengan mencantumkan nama pencipta baik nama asli maupun samaran di dalam hasil ciptaannya. ${ }^{3}$ Namun masih banyak yang tidak memahami tentang pentingnya Hak Ekonomi pencipta sehingga menimbulkan kerugian bagi pencipta karena hasil ciptaannya dengan mudahnya di perbanyak bahkan tanpa izin dari pencipta itu sendiri dengan maksud dikomersialkan.

Perlindungan hak cipta di era globalisasi saat ini lebih kompleks dan beragam. Salah satu ciptaan yang paling sering dijumpai adalah buku. Buku merupakan salah satu objek KI yang sudah memberikan sumbangan atau kontribusi untuk meningkatkan kualitas dari SDM (sumber daya manusia). Karya-karya tersebut bisa berupa dalam bentuk buku cetak (printed book), bentuk buku elektronik (E-book) dan bisa juga berwujud dalam format sebagai berikut ( $d o c, p d f, t x t, j p g$ ) serta dapat didownload dan dibaca lewat

1 Dharmawan, Supasti, Wayan Wiryawan, dkk. Harmonisasi Hukum Hak Kekayaan Intelektual. (Denpasar, Bali: Swasta Nulus, 2018), 7

2 Kumalasari, Nuzulia. "Pentingnya Perlindungan Hak Kekayaan Intelektual (HKI) Dalam Era Globalisasi." Qistie Jurnal Ilmu Hukum 3, no. 3: 15.

3 Suryo, Baskoro. Implementasi Hak Kekayaan Intelektual (Hak Cipta, Merek, Paten, Desain Industri) Seni Rupa, Kriya, dan Desain. (Yogyakarta, BP ISI Yogyakarta, 2015), 29. 
perangkat elektronik. Bentuk buku cetak maupun yang versi digital tentunya mempunyai kelebihan dan kekurangannya tersendiri. Sebagai contoh kelebihan dari buku versi cetak yaitu mempunyai ISBN (International Serial Book Number). Adanya ISBN pada buku versi cetak artinya sudah terpercaya dan dapat dijadikan sebagai acuan untuk kaum akademisi sebagai referensi dalam membuat dan juga menyusun karya ilmiah yang sedang dibuatnya. ${ }^{4}$

Perkembangan teknologi memberikan kemudahan bagi manusia untuk mengakses berbagai macam informasi. Kebutuhan manusia akan informasi pada akhirnya semakin besar mengikuti perkembangan teknologi yang dibarengi dengan arus globalisasi. Saat ini, manusia menjadi saling berintegrasi tidak hanya untuk mengakses informasi, juga untuk saling bertukar informasi dengan individu maupun kelompok lainnya. Kebebasan pertukaran informasi ini turut mempengaruhi gaya konsumsi manusia terhadap beragam jenis informasi termasuk media yang digunakan. Perubahan dinamis yang terjadi menyebabkan kemudahan akses yang semakin mudah dan bahkan manusia dapat mengakses buku cetak yang dapat diubah dalam bentuk digital. Hal ini dapat mempermudah mobilitas manusia yang semakin padat namun juga dapat mengakses informasi dari buku dalam waktu yang bersamaan. Sehingga dalam perkembangannya buku cetak kemudian dikonversi menjadi bentuk digital. ${ }^{5}$

Versi digital dari buku cetak dinamakan E-book, E-book ini memerlukan media elektronik yang dapat berupa (laptop/computer, smartphone, tablet) untuk membacanya. Ebook adalah benda digital (benda elektronik), maka sifat-sifat yang dimiliki dari E-book ini pastinya secara otomatis mempunyai sifat dari benda-benda digital pada umumnya, sebagai contoh karakteristik yang diberikan dari benda digital yaitu semakin mudahnya untuk memperbanyak/menggandakan yang kemudian akan disebarkan. Hal ini terjadi karena pesatnya penggunaan internet sebagai teknologi yang baru, hal inilah yang membuat kondisi jumlah dari buku digital beredar sangat banyak bahkan melampaui dari versi cetaknya. ${ }^{6}$

Undang-Undang Nomor 28 Tahun 2014 tentang Hak Cipta (yang selanjutnya disebut UUHC) khususnya pada pasal 40 Ayat (1) huruf a menjelaskan bahwa buku termasuk ciptaan yang dilindungi:7 Walaupun UUHC memberikan proteksi atau perlindungan hukum baik itu terhadap hak cipta, pencipta dan pemegang hak ciptanya, tetapi dalam implementasinya ternyata masih saja terdapat penyimpangan di bidang hak cipta dan untuk yang melakukan penyimpangan hak cipta dapat dituntut secara hukum. Sebagai contoh pelanggaran yang sering terjadi terhadap versi buku digital atau E-Book yaitu dibajak dan dijual. Dengan harga jual yang ditawarkan pun biasanya relatif sangat murah yaitu mulai Rp. 5000. Sebagai contoh yang dilakukan pada dua akun Instagram yaitu nuel.ebook dan ebook-kuu2. Mereka menjual buku dan novel yang bestseller dengan harga mulai dari Rp. 5000, bahkan di salah satu akun tersebut mereka menjualnya Rp. 5000 mendapatkan 12 E-book dengan metode pembayaran bisa melalui pulsa, ataupun transfer antar rekening bank.

Berdasarkan Pasal 40 Ayat (1) UUHC tidak dijelaskan secara spesifik tentang karya cipta yang dilindungi seperti E-book. Dalam pasal tersebut hanya menyebutkan

4 Kusmawan, Denny. "Perlindungan Hak Cipta Atas Buku." Perspektif 19, no. 2 (2014): 137-143.

5 Irawati. "Digital Right Managements (Teknologi Pengaman) Dalam Perlindungan Terhadap Hak Cipta Di Era Digital." Diponegoro Private Law Review 4, No. 1 (2019): 382-389

6 Labetubun, Muchtar Anshary Hamid. "Aspek Hukum Hak Cipta Terhadap Buku Elektronik (E-Book) Sebagai Karya Kekayaan Intelektual." SASI 24, no. 2 (2019): 138-149.

7 Damian, Eddy. Hukum Hak Cipta. (Bandung: PT. Alumni, 2005), 137 
tentang buku saja, dan tidak membahas tentang bagaimana sistem perlindungan e-book, karena pengertian buku sangat luas dan banyak jenisnya. ${ }^{8}$ Sehingga menimbulkan multitafsir yang berujung kekaburan norma hukum. Bertitik tolak dari permasalahan tersebut akan dikaji dalam tulisan jurnal yang berjudul: "Perlindungan Hak Cipta Pada Buku Elektronik (E-book) di Indonesia"

\subsection{Rumusan Masalah}

1. Bagaimana Pengaturan mengenai Buku Digital atau Elektronik (E-book) sebagai salah satu Aspek Hak Cipta menurut UUHC?

2. Bagaimana Bentuk Penyelesaian Sengketa yang Dapat Ditempuh Apabila Terjadi Pelanggaran Hak Cipta pada Buku Elektronik (E-book)?

\subsection{Tujuan Penulisan}

Penulisan ini bertujuan untuk mengetahui pengaturan mengenai buku digital atau elektronik (E-book) menurut UUHC, dan juga mengetahui apa saja bentuk penyelesaian sengketa yang dapat ditempuh apabila terjadi pelanggaran hak cipta pada buku elektronik (E-book).

\section{Metode Penelitian}

Penulisan jurnal ini menggunakan metode penelitian secara hukum normatif. Yaitu jenis penelitian yang sering digunakan dalam mengkaji suatu norma dalam peraturan perundang-undangan yang sudah dirumuskan secara jelas dan tidak multitafsir, apakah terdapat pertentangan norma, atau apakah suatu peraturan perundang-undangan tidak mengatur suatu perbuatan hukum yang seharusnya diatur terlebih dahulu. ${ }^{9}$ Penulis menggunakan pendekatan perundang-undangan yaitu UUHC sebagai objek kajian. Teknik yang digunakan adalah metoda kepustakaan (library research). Sumber-sumber literatur akan dijadikan sebagai rujukan dalam mengkaji masalah yang diteliti oleh penulis. Literatur berupa buku-buku dipilih berdasarkan relevansi masalah dan tentunya dapat mendukung topik penelitian. Lalu berikutnya ada jurnal-jurnal ilmiah yang tersebar di internet dan diunduh oleh penulis untuk melengkapi sumber-sumber akademik yang diperlukan. Dan demikian juga dengan hasil-hasil penelitian terdahulu yang terkait dengan tema penelitian yang juga akan menjadi bahan bacaan dan sumber rujukan.

\section{Hasil dan Pembahasan}

\subsection{Pengaturan mengenai Buku Elektronik (e-book) menurut UUHC}

Perkembangan teknologi informasi yang sangat pesat khususnya dalam pengembangan internet dan program komputer memberikan dampak yang besar khususnya pada dunia hukum, terutama yang bersinggungan dengan industri serta hak cipta. Dalam realitanya ternyata pemahaman dan juga kesiapan dari masyarakat

8 Damayanti, Ni Putu Utami Indah, AA Sri Indrawati, dan AA Sagung Wiratni Darmadi. "KARYA CIPTA ELECTRONIC BOOK (E-BOOK): STUDI NORMATIF PERLINDUNGAN HAK EKONOMI PENCIPTA." Jurnal Kertha Semaya 3, No. 3 (2015): 1-16

9 Efendi, Jonadi dan Ibrahim, Johnny. "Metode Penelitian Hukum: Normatif dan Empiris". (Depok, Permada Media Group, 2018), 123 
terhadap hukum belum dapat mengimbangi hal-hal yang disebabkan dari penggunaan teknologi informasi tersebut. 10

Versi digital dari buku cetak yaitu buku elektronik (E-book), bila umumnya buku itu terdiri atas rangkaian kertas yang di dalamnya berisi teks maupun ilustrasi, maka pada buku elektronik berisi informasi yang berbentuk digital dan dapat berupa teks maupun gambar. Buku elektronik lebih digemari karena bentuknya yang lebih simpel jika dibandingkan dengan buku versi cetaknya, serta bisa diakses dimana saja karena adanya fitur internet, dan mempunyai fitur pencarian yang memudahkan pembaca menemukan kalimat atau kata yang ingin dicari.

Format buku elektronik yang terkenal ada beberapa macam, yaitu seperti format teks polos, doc, $p d f$, html. Format-format ini tentunya mempunyai kelebihan dan juga kekurangannya masing-masing tergantung juga pada perangkat apa yang digunakan saat membuka dan membaca (E-book). Salah satu usaha yang bisa dilakukan untuk menjaga sumber referensi berbentuk buku yang jumlahnya sangat banyak dan biaya yang dikeluarkan untuk perawatannya pun relatif mahal adalah mengkonversi dari bentuk buku cetak menjadi bentuk buku elektronik (E-book). Dengan langkah ini dapat memberikan ruang yang cukup banyak dan mampu menghemat biaya yang dikeluarkan untuk merawat serta menjaga referensi-referensi berbentuk buku tersebut.

Amazon merupakan salah satu perusahaan yang melakukan pengembangan terhadap E-book, mereka menggunakan E-book karena mudah untuk dibaca di mana saja dan kapanpun melalui salah satu tablet yang mereka luncurkan yaitu Kindle. E-book bisa dibuka melalui berbagai macam software seperti contoh, yaitu ada Microsoft Word, Adobe Acrobat, dan masih ada yang lainnya bergantung pada format yang dimiliki. ${ }^{11}$ Di Indonesia terdapat beberapa toko buku digital yang berkembang, yaitu Buqu, Scoop, Aksara Maya. Dan juga ada sebagian penerbit yang membuka dan melakukan ekspansi toko buku versi digital secara pribadi, yaitu Gramediana (Gramedia), UI Press, Udayana Press, Penerbit ITB, Unsri Press, IPB Press. ${ }^{12}$

Popularitas dari suatu E-book yang sering digunakan bergantung pada tingkat kesediaan buku-buku elektronik dengan beberapa format dan tingkat kemudahan perangkat yang dipakai saat membaca dengan jenis format tersebut. ${ }^{13}$ Beberapa contoh format E-book yang terkenal antara lain EPUB (Electronic Publication), AZW (Amazon World), KF8 (Kindle Fire), dan PDF (Portable Document Format). ${ }^{14}$ Format buku elektronik (e-book) yang di sebutkan diatas selalu mengikuti jenis perangkat apa yang digunakan untuk membacanya, jadi tidak menutup kemungkinan karena semakin berkembangnya suatu teknologi maka akan muncul suatu format yang lebih baru dari buku elektronik (E-book) yang menyepadankan dengan keperluan para penggunanya.

10 Labetubun, Muchtar AH. "Perlindungan Hukum Desain Industri Di Dunia Maya (Kajian Overlaping antara Hak Cipta Dengan Hak Desain Industri)." Jurnal Sasi 17, no. 4 (2011).

11 Karmawan, I Gusti Made. (2014). Dampak Peningkatan Kepuasan Pelanggan Dalam Proses Bisnis E-Commerce Pada Perusahaan Amazon.Com, Jurnal, ComTech Vol. 5 No. 2. h. 748762

12 Nurbaiti, Dewi. "Perkembangan Ebook Dalam Industri Penerbitan Buku Fisik Serta Pertumbuhan Minat Menulis Buku." Ikra-Ith Ekonomika 2, no. 2 (2019): 11-20.

13 Lestari, Rina Tiya, Eka Pramono Adi, and Yerry Soepriyanto. "E-Book Interaktif." Jurnal Kajian Teknologi Pendidikan 1, no. 1 (2018): 71-76.

14 Prakoso, Ario Adi. "Implementasi Undang-Undang Hak Cipta No. 28 Tahun 2014 pada Aktivitas Reprografi Koleksi Digital." Lentera Pustaka: Jurnal Kajian Ilmu Perpustakaan, Informasi dan Kearsipan 5, no. 1 (2019): 21-31. 
Buku elektronik (e-book) memberikan perubahan yang sangat signifikan terutama dalam metode pembelajaran dan juga dalam penelitian akademik. E-book memberikan kemudahan yaitu dapat diakses dimana saja tanpa memperhatikan waktu dan juga tempat, bisa dibaca melalui Personal Computer (PC), Smartphone, Tablet. E-book memiliki keunggulan dalam hal aksesibilitas, penggunaan, dan biaya yang relatif murah. Karena keunggulan yang dimiliki oleh E-book ini maka tidak heran jika para akademisi pun menjadikan E-book sebagai satu dari beberapa sumber pada pengetahuan dan penelitian yang mereka lakukan. Pada tahun 2018 pihak Springer melakukan suatu survey dan memperoleh hasil bahwa banyak yang menelusuri E-book sebagai sasaran dari penelitian dan juga kajian yang mereka lakukan. Jenis E-book yang kerap digunakan adalah Buku Teks (textbooks) dan karya-karya rujukan (reference works). Google serta perpustakaan online merupakan aplikasi yang paling sering digunakan untuk mengakses E-book. Meskipun E-book banyak digemari karena keunggulan dan kemudahan yang diberikan namun tidak sedikit pengguna yang menyukai versi buku cetak karena pengguna tidak memiliki keahlian juga ada kenikmatan dalam membaca buku versi cetak (ease and enjoyability of reading). ${ }^{15}$

Proses pengalihwujudan buku cetak menjadi buku elektronik dewasa ini selayaknya juga mendapatkan perlindungan secara hukum. Hukum hadir dan mempunyai fungsi sebagai suatu alat perlindungan untuk mencapai keadilan bagi kepentingan manusia itu sendiri, dan agar kepentingan manusia dapat dilindungi, maka hukum itu harus ditegakkan dan juga diterapkan. Pelaksanaan hukum bisa dilakukan secara formal, baik dan juga damai namun bisa terjadi karena adanya pelanggaran terhadap hukum. Untuk mencapai keadilan, penegakan hukum merupakan aspek yang fundamental terutama bagi pencari keadilan.

Hasil penemuan yang berasal dari kreatifitas intelektual manusia dalam bidang ilmu pengetahuan, seni dan sastra itu disebut dengan Hak Cipta. Hasil karya yang diciptakan tersebut akan mendapatkan proteksi secara hukum apabila ciptaan itu telah diwujudkan sehingga dapat dilihat, dibaca, didengarkan dsb, bukan hanya berupa ide semata. Dalam ruang lingkup hak cipta permasalahan yang timbul itu tidak dapat diukur, karena tidak hanya membahas tentang hak-hak individu dalam lingkup nasional, tapi juga menyangkut permasalahan yang terjadi dalam lingkup internasional khususnya dalam bidang hak cipta. ${ }^{16}$

UUHC tidak memperbolehkan perbuatan mengambil ataupun mengutip tanpa izin dari pencipta karena beberapa hal ini, yaitu: ${ }^{17}$ dapat merugikan pencipta/ pemegang hak cipta, sebagai contoh melakukan penyalinan sebagian ataupun seluruh bagian dari ciptaan orang lain yang lalu dikormesialkan kepada publik; merugikan kepentingan negara; dan juga bertentangan pada ketertiban umum dan melanggar kesusilaan, sebagai contoh menggandakan dan mengkomersialkan buku elektronik ( $E$ book).

15 Labetubun, Muchtar Anshary Hamid. "Aspek Hukum Hak Cipta Terhadap Buku Elektronik (E-Book) Sebagai Karya Kekayaan Intelektual." SASI 24, no. 2 (2019): 138-149.

16 Labetubun, Muchtar Anshary Hamid, and Sabri Fataruba. "Peralihan Hak Cipta Kepada Ahli Waris Menurut Hukum Perdata." SASI 22, no. 2 (2019): 1-11.

17 Mike, Etry. "PERLINDUNGAN HUKUM HAK KEKAYAAN INTELEKTUAL TERHADAP TINDAKAN PELANGGARAN PEMBAJAKAN BUKU ELEKTRONIK MELALUI MEDIA ONLINE." AL IMARAH: JURNAL PEMERINTAHAN DAN POLITIK ISLAM 2, no. 2 (2019). 
Dalam UUHC khususnya dalam Pasal 40 Ayat (1) huruf n. Secara implisit mengakui bahwa buku digital atau elektronik (E-book) adalah salah satu karya adaptasi yang mendapatkan perlindungan. Maka dari itu tegasnya, buku elektronik (E-book) adalah bentuk adaptasi atau pengalihwujudan dari buku cetak sehingga buku elektronik (E-book) harus dilindungi. Kemudian, pasal 40 ayat (2) juga memberikan suatu penegasan bahwa ciptaan adaptasi juga mendapatkan perlindungan sebagaimana layaknya perlindungan terhadap ciptaan asli.

Untuk menghindari adanya pelanggaran terhadap penggandaan buku elektronik (e-book), maka dapat dibuat suatu perjanjian lisensi. Perjanjian lisensi ini dimaksudkan sebagai bentuk apresiasi atau penghargaan terhadap karya cipta orang lain melalui pemberian royalti kepada pemegang hak cipta atau dalam hal ini kepada pencipta itu sendiri sebagaimana diatur dalam Pasal 80 Ayat (3) UUHC. Berkaitan dengan hal tersebut, perjanjian lisensi yang dibuat tunduk pada ketentuan Pasal 1320 KUHPer tentang syarat perjanjian yang sah yang meliputi adanya kesepakatan di antara para pihak, adanya kecakapan di antara pihak, objek yang diperjanjikan tertentu atau jelas, serta perjanjian tersebut didasarkan oleh sebab atau kausa yang diperbolehkan.

\subsection{Bentuk Penyelesaian Sengketa yang Dapat Ditempuh Apabila Terjadi Pelanggaran Hak Cipta pada Buku Elektronik (E-book)}

Berdasarkan Pasal 95 Ayat (1) UUHC, jika terjadi pelanggaran hak cipta dalam penggandaan buku tanpa izin dari pencipta maupun pemegang hak cipta maka para pihak dapat menyelesaikan sengketa tersebut melalui pengadilan dan tanpa melalui pengadilan. Penyelesaian perkara tanpa melalui pengadilan terdiri dari arbitrase, mediasi, negosiasi, dan konsiliasi. Khusus untuk jalur pengadilan, hanya Pengadilan Niaga yang berwenang untuk menyelesaikan perkara hak cipta.

Pengaturan penyelesaian sengketa di bidang hak cipta khususnya jalur non litigasi tidak diatur secara spesifik karena tidak menguraikan defines dan konsep-konsep pelaksanannya. Kemudian, salah satu hal yang menjadi pusat perhatian dalam penyelesaian sengketa di bidang hak cipta adalah adanya pengaturan yang tegas perihal fungsi hukum pidana sebagai ultimum remedium. Hal tersebut dapat dilihat dari ketentuan Pasal 95 Ayat (4) UUHC yang secara expressis verbis mengatur bahwa tuntutan pidana baru dapat diajukan apabila para pihak yang bersengketa telah menempuh upaya mediasi. Dengan demikian mediasi merupakan langkah hukum yang wajib ditempuh karena sudah diperintahkan oleh pembentuk undang-undang. Seluruh ketentuan pidana yang diatur dalam UUHC digolongkan oleh pembentuk undangundang sebagai delik aduan.

Apabila berdasarkan putusan pengadilan perkara perdata terbukti bahwa telah terjadi pelanggaran hak cipta, maka pihak yang terbukti bersalah wajib memberikan ganti rugi. Sedangkan apabila berdasarkan putusan pengadilan perkara pidana terbukti bahwa telah terjadi pelanggaran hak cipta, maka pihak yang terbukti bersalah dijatuhi pidana penjara dan/atau pidana denda.

\section{Kesimpulan}

Penjelasan dari Pasal 40 Ayat (1) huruf n UUHC secara implisit mengakui bahwa buku elektronik (E-book) merupakan salah satu ciptaan adaptasi yang dilindungi. Maka dari itu tegasnya, buku elektronik (E-book) adalah bentuk adaptasi atau pengalihwujudan dari buku cetak sehingga buku elektronik (E-book) harus dilindungi. Bagi orang lain yang ingin mengkonversi buku cetak menjadi buku elektronik (E-book) harus mendapatkan izin dari penciptanya melalui perjanjian lisensi yang dibuat oleh 
para pihak dan tunduk pada ketentuan Pasal 132 tentang syarat dalam membuat perjanjian. Apabila terdapat pelanggaran hak cipta dalam penggandaan buku elektronik tanpa seizin dari Pencipta berdasarkan Pasal 95 Ayat (1) UUHC, maka para pihak dapat menyelesaikan perkara melalui pengadilan dan tanpa melalui pengadilan. Penyelesaian perkara tanpa melalui pengadilan dapat dilakukan dengan cara arbitrase, mediasi, negosiasi, dan konsiliasi. Khusus untuk jalur pengadilan, hanya pengadilan niaga yang berwenang untuk menyelesaikan perkara hak cipta.

\section{DAFTAR PUSTAKA}

Buku:

Dharmawan, Supasti, Wayan Wiryawan, dkk. Harmonisasi Hukum Hak Kekayaan Intelektual. (Denpasar, Bali: Swasta Nulus, 2018)

Efendi, Jonadi dan Ibrahim, Johnny. "Metode Penelitian Hukum: Normatif dan Empiris". (Depok, Permada Media Group, 2018)

Suryo, Baskoro. Implementasi Hak Kekayaan Intelektual (Hak Cipta, Merek, Paten, Desain Industri) Seni Rupa, Kriya, dan Desain. (Yogyakarta, BP ISI Yogyakarta, 2015)

\section{Jurnal:}

Damayanti, Ni Putu Utami Indah, AA Sri Indrawati, dan AA Sagung Wiratni Darmadi. "KARYA CIPTA ELECTRONIC BOOK (E-BOOK): STUDI NORMATIF PERLINDUNGAN HAK EKONOMI PENCIPTA." Jurnal Kertha Semaya 3, No. 3 (2015): 1-16.

Irawati. “Digital Right Managements (Teknologi Pengaman) Dalam Perlindungan Terhadap Hak Cipta Di Era Digital." Diponegoro Private Law Review 4, No. 1 (2019)

Karmawan, I. Gusti Made. "Dampak Peningkatan Kepuasan Pelanggan dalam Proses Bisnis E-Commerce pada Perusahaan Amazon. Com." ComTech: Computer, Mathematics and Engineering Applications 5, no. 2 (2014): 748-762.

Kusmawan, Denny. "Perlindungan Hak Cipta Atas Buku." Perspektif 19, no. 2 (2014): 137143.

Kumalasari, Nuzulia. "Pentingnya Perlindungan Hak Kekayaan Intelektual (HKI) Dalam Era Globalisasi." Qistie Jurnal Ilmu Hukum 3, no. 3: 15.

Labetubun, Muchtar AH. "Perlindungan Hukum Desain Industri Di Dunia Maya (Kajian Overlaping antara Hak Cipta Dengan Hak Desain Industri)." Jurnal Sasi 17, no. 4 (2011).

Labetubun, Muchtar Anshary Hamid, and Sabri Fataruba. "Peralihan Hak Cipta Kepada Ahli Waris Menurut Hukum Perdata." SASI 22, no. 2 (2019): 1-11.

Labetubun, Muchtar Anshary Hamid. "Aspek Hukum Hak Cipta Terhadap Buku Elektronik (E-Book) Sebagai Karya Kekayaan Intelektual." SASI 24, no. 2 (2019): 138-149.

Lestari, Rina Tiya, Eka Pramono Adi, and Yerry Soepriyanto. "E-Book Interaktif." Jurnal Kajian Teknologi Pendidikan 1, no. 1 (2018): 71-76.

Mike, Etry. "PERLINDUNGAN HUKUM HAK KEKAYAAN INTELEKTUAL TERHADAP TINDAKAN PELANGGARAN PEMBAJAKAN BUKU ELEKTRONIK MELALUI MEDIA ONLINE." AL IMARAH: JURNAL PEMERINTAHAN DAN POLITIK ISLAM 2, no. 2 (2019).

Nurbaiti, Dewi. "Perkembangan Ebook Dalam Industri Penerbitan Buku Fisik Serta Pertumbuhan Minat Menulis Buku." Ikra-Ith Ekonomika 2, no. 2 (2019): 11-20. 
Prakoso, Ario Adi. "Implementasi Undang-Undang Hak Cipta No. 28 Tahun 2014 pada Aktivitas Reprografi Koleksi Digital." Lentera Pustaka: Jurnal Kajian Ilmu Perpustakaan, Informasi dan Kearsipan 5, no. 1 (2019): 21-31.

\section{Peraturan Perundang-Undangan:}

Undang-Undang Nomor 28 Tahun 2014 tentang Hak Cipta (Lembaran Negara Republik Indonesia Tahun 2014 Nomor 266, Tambahan Lembaran Negara Republik Indonesia Nomor 5599)

Kitab Undang-Undang Hukum Perdata 